\title{
Shear behavior of light weight ferrocement concrete slabs
}

\author{
Prof.Yousry B.I.Shaheen ${ }^{1}$ Dr. Amal A. Naser ${ }^{2}$ Eng. Wesam S. El-Habashy ${ }^{3}$ \\ ${ }^{I}$ Prof. of strength and testing of materials, ${ }^{1}$ E-mail: ybishaheen@yahoo.com \\ ${ }^{2}$ Lecture at civil engineering department, ${ }^{3}$ PhD Student
}

\begin{abstract}
The objective of the work presented in this research was to develop light weight composite slab subjected to punching load by using column slab connection at the center of the slab which comprises polystyrene block of thickness $80 \mathrm{~mm}$ reinforced with welded galvanized steel mesh or expanded steel mesh. The use of expanded metal mesh and welded steel mesh was proposed as a viable alternative to ordinary steel bars in reinforcing ferrocement plates, also it was proposed to use it with ordinary steel bars to enhance the mechanical behavior of the composite slab. For light weight sandwich elements, light weight polystyrene of density $12 \mathrm{Kg} / \mathrm{m} 3$ is used as a core material and welded wire meshes or expanded steel meshes are to be used as steel reinforcement at the two thin skin layers. Twelve squares composite light weight slabs were developed having the dimensions of $1200 \mathrm{~mm} \times 1200 \mathrm{~mm}$ and overall thickness of $140 \mathrm{~mm}$ were tested simply supported along all four sides under central column slab connection until failure. This research presents the behavior of ferrocement lightweight slabs under punching shear. The effects of various types of reinforcing materials were investigated. Using such lightweight materials will contribute to decreasing the weight of the elements and consequently decreasing the overall dead load of the building. Moreover, the study aimed at improving some other characteristics like flexural strength, crack pattern, first crack load, crack width, and deflection.
\end{abstract}

Keywords: Lightweight; ferrocement; punching shear; steel meshes; structural behavior; cracking pattern; ductility ratio; energy absorption.

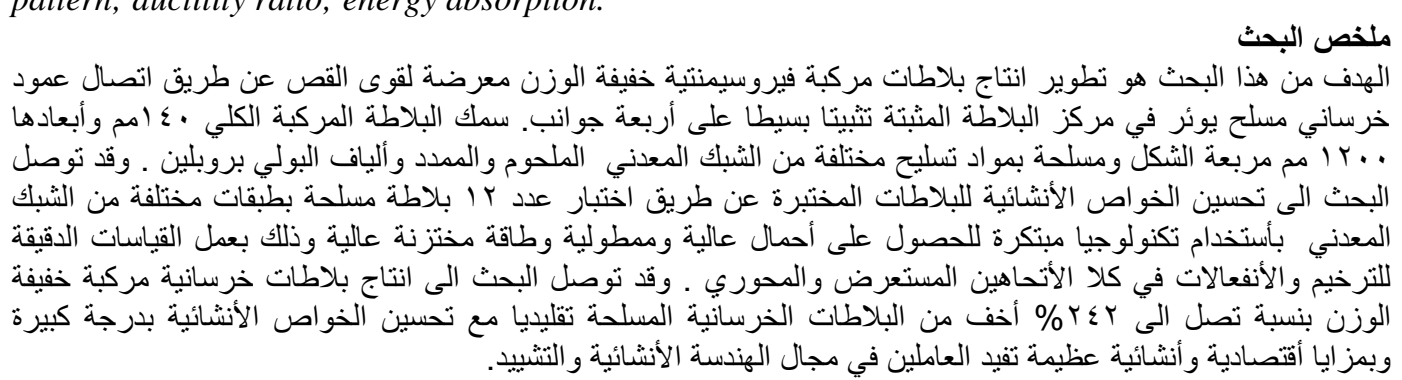

\section{Introduction}

Ferrocement (FC) is defined as a thin-wall reinforced concrete commonly constructed of hydraulic cement mortar reinforced with closely spaced layers of continuous and relatively small diameter mesh. Ferrocement primarily differs from conventional reinforced concrete and prestressed concrete by mainly in the manner by which reinforcing elements are dispersed and arranged ${ }^{(1)}$ FC has been used for at least 150 years as a boat building material due to its strength and its ability to resist $\operatorname{corrosion}^{(2)}$. Ferrocement was firstly known in 1852 in France when the first boat was built using this technology; it was firstly known as "Ferciment (1) Early, Ferrocement technology had limited applications like garden benches, boats, and water tanks; however, due to the many researches that were conducted on ferrocement recently, the applications of ferrocement have become versatile such as load bearing applications, different roofing systems, repair works, water structures like tanks, and precast ferrocement elements $^{(3)}$. Ferrocement as a construction technique is defined by $\mathrm{ACI}^{(4)}$ as follows: "Ferrocement is a form of reinforced concrete using closely spaced multiple layers of mesh and/or small diameter rods completely infiltrated with, or encapsulated in, mortar. The most common type of reinforcement is steel mesh. Other materials such as selected organic, natural or synthetic fibers may be combined with metallic mesh.(4). Housing demand is increasing due to the increasing of population worldwide, especially in developing countries, where the problem of the 
housing for the poor is a dilemma. Moreover, the increasing costs of the construction materials, equipment, and labor cause the problem to be even worse. Therefore, new building materials and methodology have to be developed in order to narrow the gap between the continuous increasing housing demand and the high cost of construction materials (5). One of the new methodologies that have been developed to overcome this problem is the Ferrocement Technology. Ferrocement seems to offer the following advantages: reduction in construction time, better quality control, materials and labor savings, and reduction in construction cost (24). Furthermore, ferrocement units produced were found to satisfy such requirements like high strength, light weight, and ease of installation. When conducting a comparison between ferrocement and conventional technology (monolithic reinforcement concrete), it was found that FC is $20-25 \%$ cheaper in small construction, savings can reach $40 \%$ in large construction, it is up to $75 \%$ lighter in weight than Reinforced Concrete (RC), it has thermal conductivity $7 \%$ less than RC, and its strength to weight ratio 3-6 times higher than $\mathrm{RC}$ and many more advantages that FC possesses compared to conventional concrete elements(15). The basic parameters, which characterize ferrocement are the specific surface area of reinforcement, the volume fraction of the reinforcement (Vf), the surface cover of the mortar over the reinforcement, and the quality of the mortar used in the ferrocement units(6). Ferrocement behaves like conventional reinforced concrete in its load bearing characteristics; however, the main difference is that crack development process is delayed by the dispersion of the reinforcement in fine form through the mortar(7). High quality can be achieved in ferrocement units if the following conditions are maintained: proper compaction of the mortar, suitable cover for reinforcement, proper shape and thickness, and quality of the elements (8). Ferrocement sandwich panel is one of the developed applications of ferrocement technology that offer an ideal building material (9). A sandwich panel consists of two thin skin layers of relatively high strength and modulus of elasticity, separated by a thick layer of a low strength material as a core. The advantage of this type of building materials is mainly the light weight of the unit compared to its equivalent volume of the conventional concrete. Such panels could be used as roof elements or as wall bearing elements. This is mainly due to the two thin skin layers at the two faces, which can carry loads, resist impacts, and accommodate architectural acceptance, while in the same time the core material provides thermal and sound insulation (9). Moreover, the core material can provide shear transfer between the two thin skin layers if the units are to be used for structural or load bearing purposes. In this case, the core material should possess adequate strength to be able to transfer the shear force between the two layers. Ferrocement lightweight sandwich panel system was investigated in previous researches and has proven that it is one of the most suitable structural systems.

\section{r. Experimental program}

Four designations series, namely A, B, C and D comprise twelve reinforced light weight ferrocement slabs were cast and tested. Series A consists of casting and testing of three slabs which reinforced with conventional reinforcement. Reinforcement of slab S1, 5 steel bars $\varnothing 6 \mathrm{~mm}$ in both directions at the top and bottom. . Reinforcement of slab S2, 3 steel bars $\varnothing$ $6 \mathrm{~mm}$ in both directions at the top and bottom. Reinforcement of slab S3, 9 steel bars $\varnothing 6 \mathrm{~mm}$ in both directions at the top and bottom. Series B consist of two slabs S4 and S6 which reinforced with steel bars and galvanized steel mesh i. Reinforcement of slab S4, 3 steel bars $\varnothing 6 \mathrm{~mm}$ in both directions at the top and bottom and one layer welded galvanized steel mesh. Slab S6, reinforcement 5 steel bars $\varnothing 6 \mathrm{~mm}$ in both directions at the top and bottom and one layer welded galvanized steel mesh. Series C comprises casting and testing of slabs S5, S7, S8, S9 and S10 which reinforced with galvanized steel mesh only with variable numbers. S5 Reinforcement of slab one layer welded galvanized steel mesh at the top and bottom. S7 Reinforcement of slab, two layers welded galvanized steel mesh at the top and bottom. Slab S8, reinforcement three layers welded galvanized steel mesh at the top and bottom. Slab S9 reinforced with four layers welded galvanized steel mesh at the top and bottom. . Slab S10 reinforced with five layers welded galvanized steel mesh at the top and bottom. Series D comprises casting and testing of slabs S11 and S12 which reinforced with expanded steel mesh. Slab S11 reinforced with one layer of expanded steel mesh while slab S12 reinforced with two layers of expanded steel mesh.

\subsection{Variables Studied}

Details of reinforcement of all series are presented in Table 1.In order to draw a good comparison between the tested slabs, including the effect of different variables on deformation characteristics, cracking performance, and ultimate strength, the variables considered were:

1. Number of reinforcing mesh layers.

2. Type of mesh used.

3. Volume fraction of steel reinforcing materials.

4. Combination of mesh and skeletal steel bars.

5. Employing light polystyrene block as core material

\subsection{Specimen Designations and Objectives of}

\section{Series}

The main objectives of the experimental program included casting and testing four series designations are as follows. 
1. To make comparison between the control slabs $\mathrm{S} 1$, $\mathrm{S} 2$ and $\mathrm{S} 3$ in series A.

2.To study the effect of increasing the number of skeletal steel bars on the structural behavior of the tested slabs and to compare them with the control testing slabs.

3. To make comparison study between slabs $\mathrm{S} 1$ which reinforced 5 steel bars $\varnothing 6 \mathrm{~mm}$ in both directions at the top and bottom and $S 9$ reinforced with four layers of welded galvanized steel mesh at the top and bottom having approximately the same volume fraction percentage, $1.376 \%$ and $1.321 \%$ respectively.

4.To compare the obtained results of slab S8 which reinforced three layers welded galvanized steel mesh at the top and bottom, volume fraction $1.139 \%$ and slab S11 which reinforced with one layer of expanded metal mesh at the top and bottom, volume fraction $1.1003 \%$.

5. To compare the structural performance of slabs in series A with those in series B, C and D.

6. To compare the structural performance of slabs in series $\mathrm{B}, \mathrm{C}$ and $\mathrm{D}$ having approximately the same volume fraction percentages.

\subsection{Casting Mold}

For casting slabs a special strong mold was designed. It consisted of $20 \mathrm{~mm}$ thick wooded sheet covered with aluminum thin sheet of $3 \mathrm{~mm}$ thick which made observation of cracks during early ages easier. Four aluminum side angles were screwed to the composite wooden plate with the dimensions required of the specimen. Fine holes were located in the side angles to allow fine steel wires to be threaded through into the holes.

\subsection{Sample Preparation and Test Setup}

The universal testing machine used in conducting the steel tensile tests for both bars and meshes was equipped with internal extensometer, the length of specimens used to test steel bars was determined as the gage length required plus the gripping distances. Bearing in mind the inherent difficulties in testing thin sheet specimens in direct tension, the test specimens were especially designed to ensure failure away from the grips and the ends of the specimen. The dimensions of the test specimens were chosen with the guidance of the method proposed by Swamy and Shaheen ${ }^{(10)}$. All the specimens had the same matrix with the mix properties of 1:2:0.4 (cement: sand: water, by weight ${ }^{(11)}$

\subsection{Core Material}

One type of core material was used to produce the ferrocement slabs under investigation. Reinforced polystyrene block of density $12 \mathrm{Kg} / \mathrm{m}^{3}$ and $8 \mathrm{~cm}$ thick was employed to provide the core material in-between the two skin ferrocement layers. The top and bottom reinforcement were tied together through welded shear connectors to a rigid cage. The thicknesses of the top and bottom ferrocement skins were kept constant as
$30 \mathrm{~mm}$. The total thickness of the innovative light weight slab

was $14 \mathrm{~cm}$.

\subsection{Test Sample and Preparation}

The panel is made up of two electro welded galvanized steel meshes positioned adjacent to the faces of a central block in wave-shape expanded polystyrene. The automatic industrial production assures the constant quality of the product. The mesh is also realized automatically and continuously by machines. The parameters that influence welding are set in these machines. The density of the panel polystyrene block is $12 \mathrm{Kg} / \mathrm{m}^{3}$. The thickness of the block is $80 \mathrm{~mm}$. The two layers of meshes are connected by means of metal connectors positioned across the nodes of $\varnothing 3 \mathrm{~mm}$. The dimensions of square panels are $1200 \mathrm{~mm} \times 1200 \mathrm{~mm}$ and $80 \mathrm{~mm}$ thick. The longitudinal reinforcement of $\varnothing$ $3.5 \mathrm{~mm}$ while the transverse reinforcement the panel of $\varnothing 2.5 \mathrm{~mm}$ as shown in Fig. 1. The steel used for the meshes is drawn with hot galvanization with ultimate strength of $600 \mathrm{~N} / \mathrm{mm}^{2}$.

\section{Behavior of ferrocement slabs}

As described in chapter three slabs were tested under central concentrated loadings acting on reinforced concrete columns having the dimensions of $12 \times 12 \mathrm{~cm}$ and length $50 \mathrm{~cm}$. The deflection at each load increment was recorded at three points on the tested slabs, at the center of the slab and in both lateral and diagonal directions of the tested slabs. To draw the load-deflection curves. Cracks initiation and their propagations were also observed for each test specimen. The effect of the parameters under investigation on the ultimate moment, maximum deflection at ultimate load, compressive strains in both lateral and diagonal directions at all stages of loadings were also measured. Ductility ratio, energy absorption, and cracking behavior are discussed in the following sections.

\subsection{Ultimate Load}

It is clear from Table 2 that using welded steel mesh and expanded steel mesh in reinforcing ferrocement slabs in series designations B, C and D is very effective in increasing their ultimate load than the other reinforcement's formation. Where ultimate load of slabs of series designation B slab S4 which reinforced with 3 steel bars $\varnothing 6 \mathrm{~mm}$ in both directions at the top and bottom and one layer welded galvanized steel mesh, Vr. $1.245 \%$ and slab S6 which reinforced with 5 steel bars $\varnothing 6 \mathrm{~mm}$ in both directions at the top and bottom and one layer welded galvanized steel mesh., $\operatorname{Vr} 1.559 \%$ is much higher than that of slab $\mathrm{S} 1$ and $\mathrm{S} 2$ in series $\mathrm{A}$ by approximately $20 \%$. In series designation C slab S7 which reinforced with two layers welded galvanized steel mesh at the top, Vr. $0.956 \%$ the ultimate load is 
approximately equal to that of slab $\mathrm{S} 1$ in series A which reinforced with 5 steel bars $\varnothing 6 \mathrm{~mm}$ in both directions at the top and bottom, $\mathrm{Vr}$ equal to 1.376 . It is significant to reach that small volume fraction of reinforcement in the form of galvanized steel mesh is much effective compared with conventional reinforcing materials. The ultimate load of slab S8 which reinforced with Three layers welded galvanized steel mesh at the top and bottom, Vr. $1.139 \%$ is much higher by approximately $20 \%$ than that of slab S2 which reinforced with 3 steel bars $\varnothing$ $6 \mathrm{~mm}$ in both directions at the top and bottom. The ultimate load of slab S9 which reinforced with Four layers welded galvanized steel mesh at the top and bottom, Vr. $1.321 \%$ is much higher with approximately $18 \%$ compared with that of slab S1, Vr. Equal $1.376 \%$. The ultimate load of slab S10 which reinforced with Five layers welded galvanized steel mesh at the top and bottom., Vr. $1.5037 \%$ is much higher than that of slab S6 which reinforced with 5 steel bars $\varnothing 6 \mathrm{~mm}$ in both directions at the top and bottom and one layer welded galvanized steel mesh. and Vr. equal to $1.559 \%$ by approximately $12 \%$. Therefore, employing galvanized welded steel mesh as reinforcing materials reaching high strength gain than employing galvanized steel mesh with skeletal steel bars. Finally comparing the ultimate loads slab S11 in series designation D which reinforced with One layer expanded metal mesh at the top and bottom, Vr. $1.1003 \%$ is much higher with $14 \%$ than that obtained in slab S2 which reinforced with 3 steel bars $\varnothing 6 \mathrm{~mm}$ in both directions at the top and bottom, Vr. $1.061 \%$. The ultimate load of slab S12 which reinforced with two layers expanded metal mesh meh at the top and bottom, Vr. $1.6099 \%$ is much higher with $8 \%$ than that of slab S6 which reinforced with 5 steel bars $\varnothing 6 \mathrm{~mm}$ in both directions at the top and bottom and one layer welded galvanized steel mesh., Vr. 1.559\%. Fig. 6 shows comparison of all first crack, serviceability and ultimate loads of all the tested slabs.

\subsection{Deflection and Ductility Ratio}

All tested slabs showed typical three-stage load versus central-span deflection relationship. Under initial loading the load-deflection response was linear up to cracking load. The second stage is defined by cracking section behavior with the steel reinforcement behaving linear elastic. Transition into third phase of behavior is marked by yielding of the tensile reinforcement and non-linear material behavior. After yielding of tension steel, slab behavior is defined by large increase in deformation with little increase in applied load. All tested plates showed large deflection at ultimate loading, which is an indication of high ductility. Figs.3-5 show the load central deflection curves of all the tested slabs.
Fig. 7 shows comparison of ductility ratios of all the tested slabs.

\subsection{Energy Absorption}

The experimental results proved that as the volume fraction for slabs increase, energy absorption increased also. It is interesting to note that plate 6 in series B. C and D exercises high ductility and energy absorption properties which are very useful in dynamic applications. Fig. 8 shows comparison energy absorptions of all the tested slabs

\subsection{Failure Modes}

For all series designation of all the tested slabs punching shear failure occurred for all the tested slabs. Fig. 10 shows the cracking patterns for all the tested slabs at tensile faces.

\section{Conclusions}

Based on the results and observations of the theoretical and experimental study presented in chapters four and five regarding the effect of silica fume on the properties of fresh and hardened concrete and the effectiveness of welded steel mesh and expanded steel mesh as a reinforcement material for slabs, the following conclusions could be drawn as follows:

1. Irrespective of the type of welded steel mesh, expanded steel mesh using three mild steel bars in both directions with one layer welded steel mesh leads to improve ductility ratio and energy absorption and consequently increase ultimate punching load than that obtained when using conventional reinforcing materials.

2. The developed composite ferrocement slabs emphasized better deformation characteristics and high serviceability loads, crack resistance and energy absorption, but it also leads to decrease the ductility ratio, Where ductility ratio decreases with the increase of reinforcement ratio.

3. Irrespective of reinforcement schemes, using welded steel mesh in reinforcing slabs and tying the top and bottom reinforcement into rigid a rigid cage with shear connectors going through polystyrene block core resulted in increased ultimate shear punching load of the composite slab and also increase energy absorption ductility ratio.

4. The volume fraction of reinforcing materials used has a great influence on the amount of gain in the resisting moment, ductility ratio, and energy absorption. The higher the steel ratio; the higher the gain in the ultimate moment and energy absorption; on the other hand, the ductility ratio was found to be decreased with the increase in the steel ratio.

5. The proposed empirical equation which models flat slab supported on composite columns predicts 
strengths was found to be in a good agreement with the experimental and numerical results.

6. There is a great saving of weight by employing lightweight composite slabs leading to easy construction especially for weak soil foundations.

7. The developed innovative composite slabs 1s lighter in weight by approximately $247 \%$ compared with conventional concrete slabs in addition with thermal and sound isolation with better deformation characteristics and high strength gain which are very useful for developed and developing countries alike.

\section{REFERENCES}

1.Ferrocement Model Code; Building Code Recommendations for Ferrocement (IFS-Committee 10-2001), International Ferrocement Society, Asian Institute of Technology, Thailand, 2001.

2.Abang Abdullah Abang Ali, "Applications of Ferrocement as a Low Cost Construction Material in Malaysia", Journal of ferrocement: Vol. 25, No. 2,

3.S.K. Kaushik et al, "Buckling of Ferrocement Plates", Journal of Ferrocement: Vol.24, No.1. January 1994, pp. $7-15$

4. Building Code Requirements for Reinforced Concrete (ACI 318M-89), American Concrete Institute, Detroit, Michigan, U.S.A.

5. Plena Egypt, Delta Sand Bricks Co "The Cost Saving Blocks", a manufacturer's catalogue
6. I.A. Basunbul, Mohamed Saleem, and G.J.AlSulaimani, "Flexural Behavior of Ferrocement Sandwich Panels", Cement and Concrete Composites, 1991, v. 13, pp 21-28

7. I.A. Basunbul, Mohamed Saleem, and G.J.AlSulaimani, "Structural Behavior of Ferrocement Load Bearing Wall Panels", Journal of Ferrocement: Vol. 20, No. 1, January 1990, pp 1-9

8. M.A. Mansur and P. Paramasivam, "Ferrocement Short Columns under Axial and Eccentric Compression", ACI Structural Journal, SeptemeberOctober 1990, pp 523-529

9. Zielinski. Z. A. et al, "Full-Scale Bearing Strength Investigation of Thin Wall-Ribbed Reinforced Concrete Panels", ACI Journal, Proceedings V. 79, July-Aug. 1982, pp. 313-321.

10. Fahmy, E.H., Shaheen, Y.B.I., \& El-Dessouki, W.M. (1995). Application of ferrocement for construction of radial gates. Journal of Ferrocement, 25(2), 115-121.

11. Fahmy, E.H., Shaheen, Y.B., Abou Zeid, M.N., \& Gaafar, H. (2004). Ferrocement sandwich and cored panels for floor and wall construction. Proceedings of the 29th Conference on Our World in Concrete \& Structures, 245-252.

12. Egyptian Code for Design and Construction of Concrete Structures, Housing and Building Research Center,

Egypt, 2001. 
Table 1 Four designations series of all innovative light weight slabs.

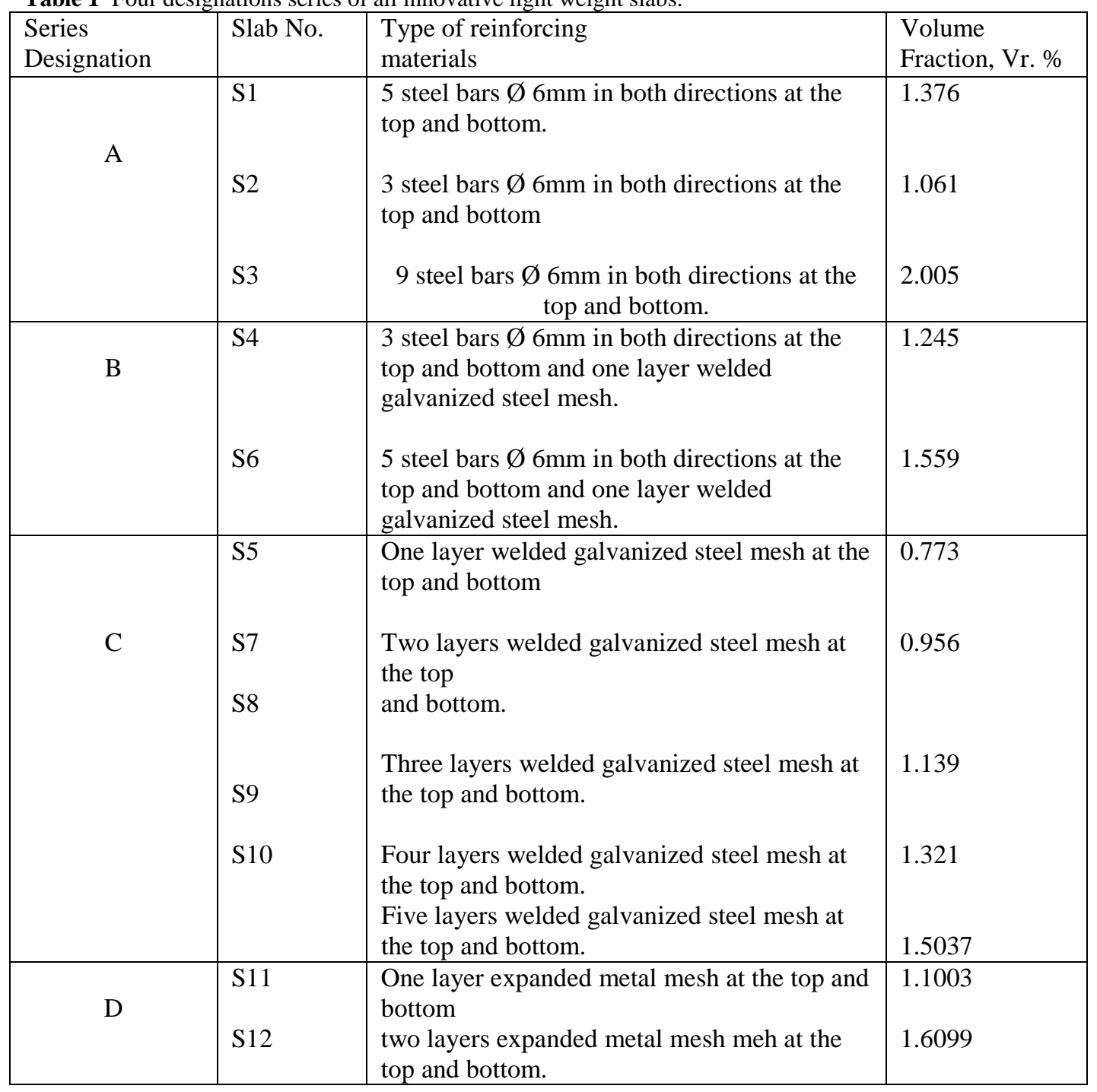

Table 2 First crack load, Serviceability load Ultimate load, Ductility ratio and Energy absorption of all the tested slabs

\begin{tabular}{|c|c|c|c|c|c|c|c|}
\hline $\begin{array}{c}\text { Slab } \\
\text { No. }\end{array}$ & $\begin{array}{c}\text { First } \\
\text { crack } \\
\text { load, KN }\end{array}$ & $\begin{array}{c}\text { Deflection } \\
\text { F.C.L.mm }\end{array}$ & $\begin{array}{c}\text { Pservice, } \\
\text { KN }\end{array}$ & $\begin{array}{c}\text { Pultimate } \\
\text { KN }\end{array}$ & $\begin{array}{l}\text { Deflection } \\
\text { Ultit.L.m } \\
\text { m }\end{array}$ & $\begin{array}{c}\text { Ductility } \\
\text { ratio }\end{array}$ & $\begin{array}{c}\text { Energy } \\
\text { Absorption } \\
\text { KN.mm }\end{array}$ \\
\hline S1 & 10 & r.93 & 19.78 & 45 & 31.11 & 10.62 & 942.28 \\
\hline S2 & 13.3 & 1.4 & 26.134 & 42 & 16.5 & 11.79 & 515.84 \\
\hline S3 & 20 & 4.79 & 18.7 & 48 & 26.5 & 5.53 & 855.47 \\
\hline S4 & 25 & 3.82 & 26.57 & 46 & 19.33 & 5.06 & 660.02 \\
\hline S5 & 20 & 3.75 & 21.08 & 40 & 38.7 & 10.32 & 1186.7 \\
\hline S6 & 25 & 6.22 & 19.96 & 50 & 36.36 & 5.85 & 1248.5 \\
\hline S7 & 20 & 3.17 & 22.46 & 45 & 25.66 & 8.094 & 804.3 \\
\hline S8 & 20 & 1.99 & 28.31 & 51 & 25.2 & 12.66 & 1010.8 \\
\hline S9 & 20 & 4.24 & 20.26 & 53 & 32.35 & 7.63 & 1137.4 \\
\hline S10 & 25 & 3.12 & 27.67 & 56 & 36.75 & 11.78 & 1491.8 \\
\hline S11 & 20 & 6.2 & 16.23 & 48 & 38.66 & 6.24 & 1319.1 \\
\hline S12 & 20 & 5.12 & 18.46 & 54 & 47.85 & 9.35 & 1818 \\
\hline
\end{tabular}




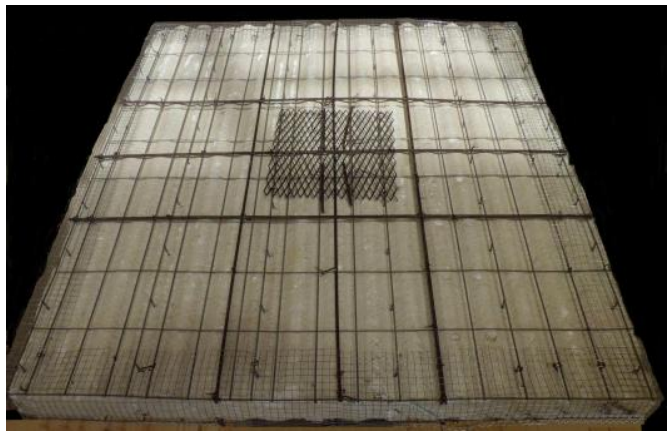

Fig. 1 Lightweight polystyrene block panel $1200 \times 1200 \mathrm{~mm}$ and $80 \mathrm{~mm}$ thick.

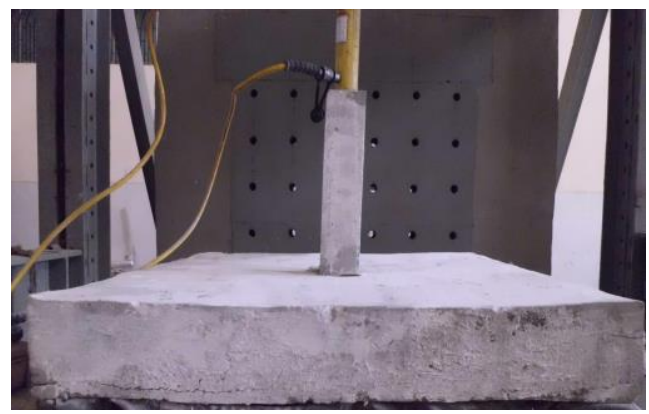

Fig.2 Test Rig
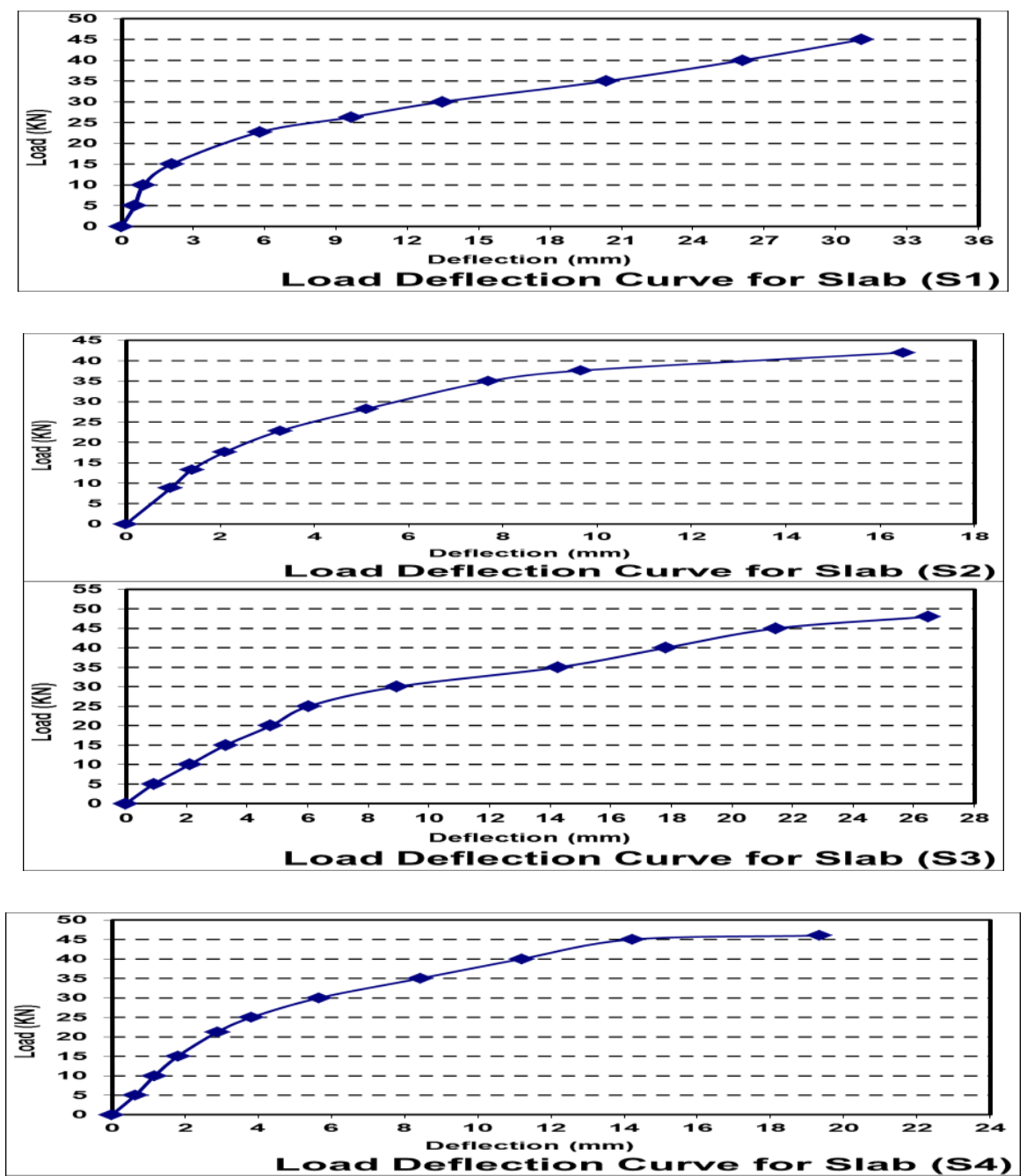

Fig. 3 Load central deflection of slabs S1-S4 

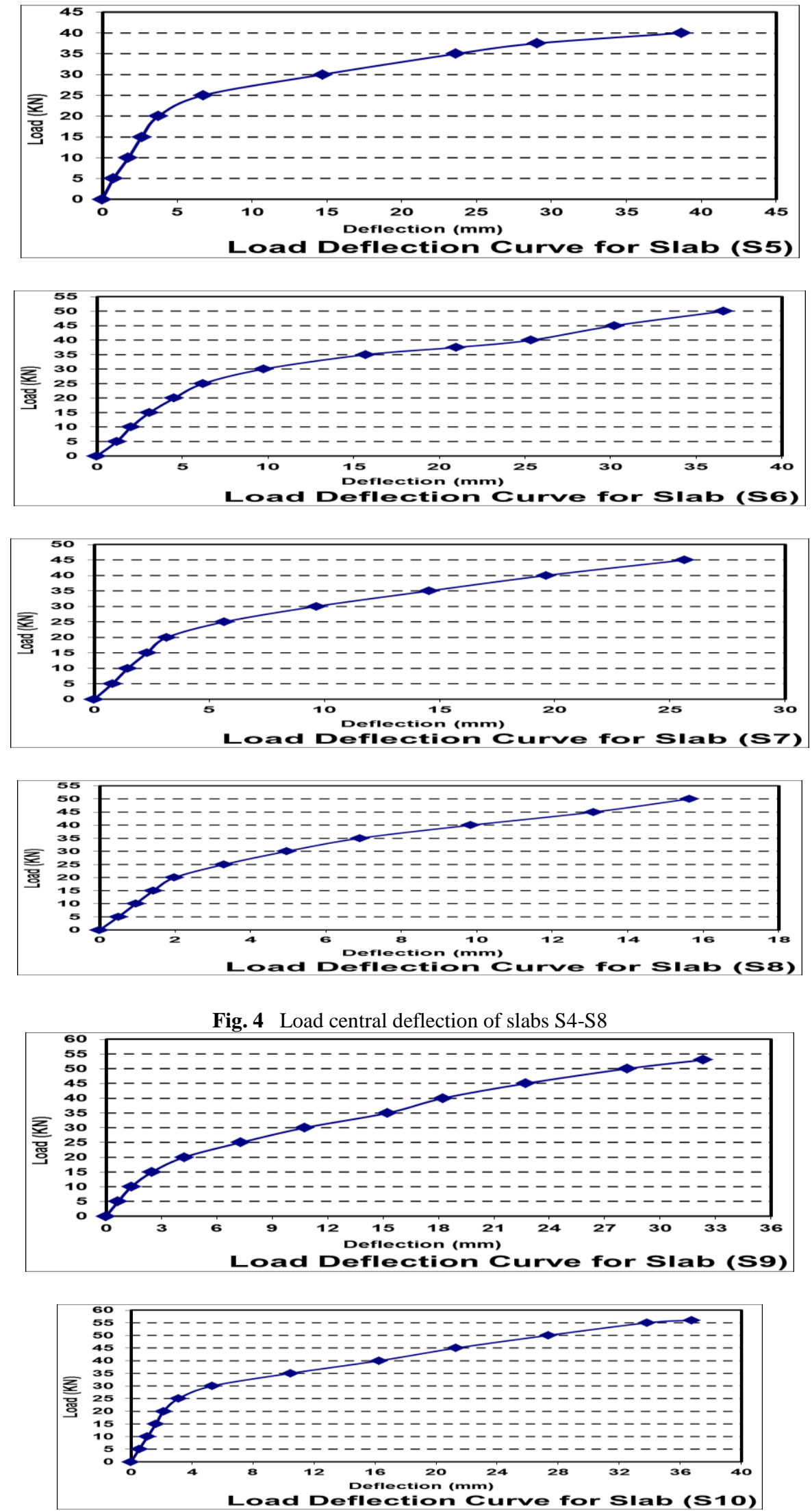

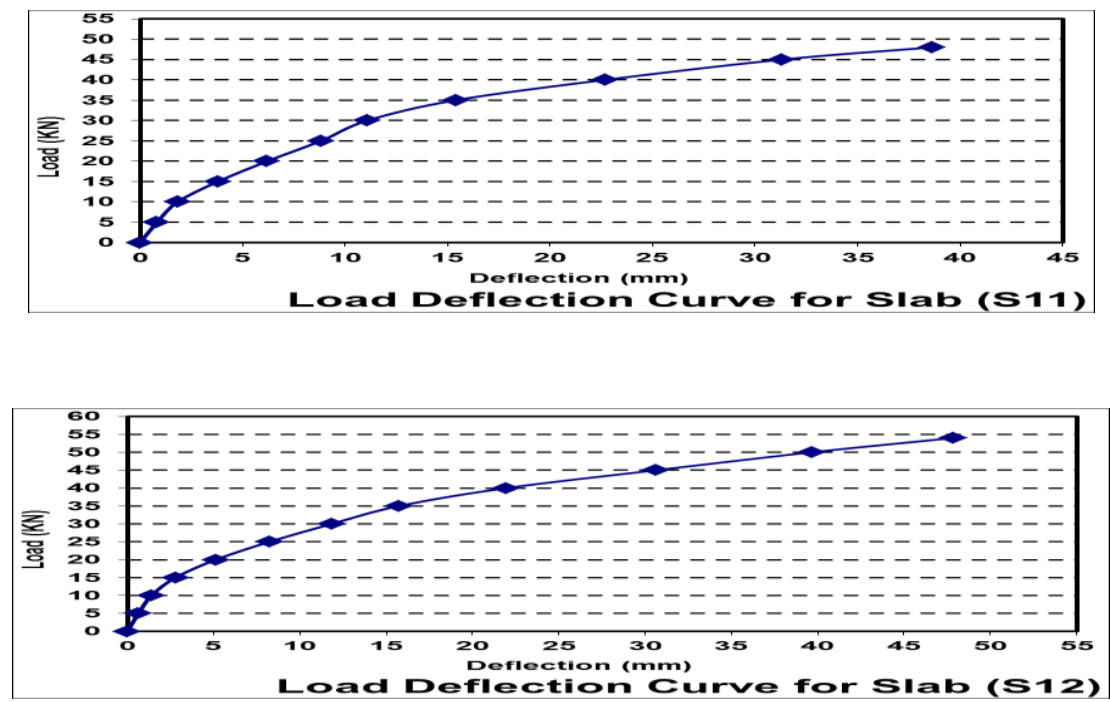

Fig. 5 Load central deflection of slabs S4-S12.
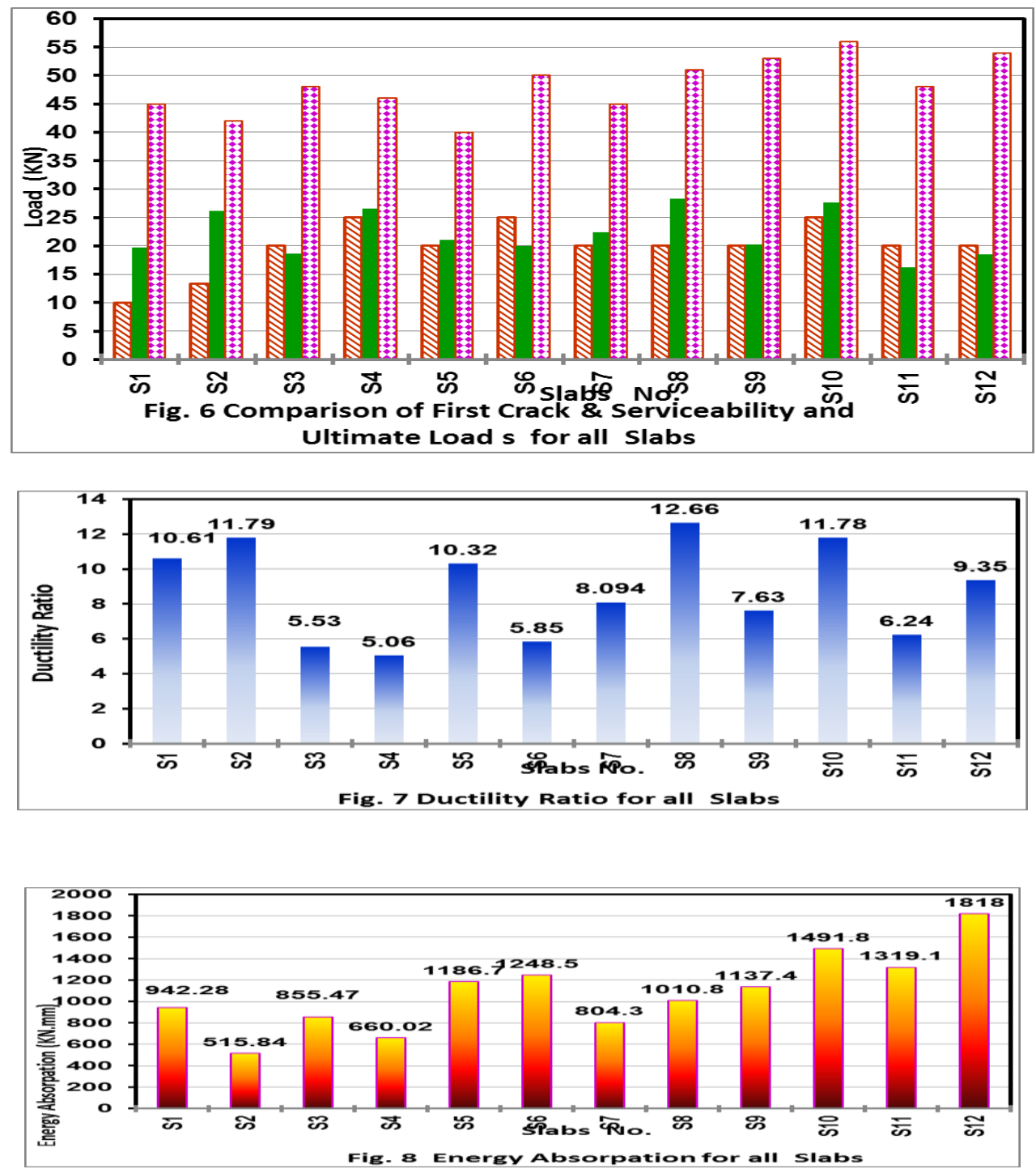

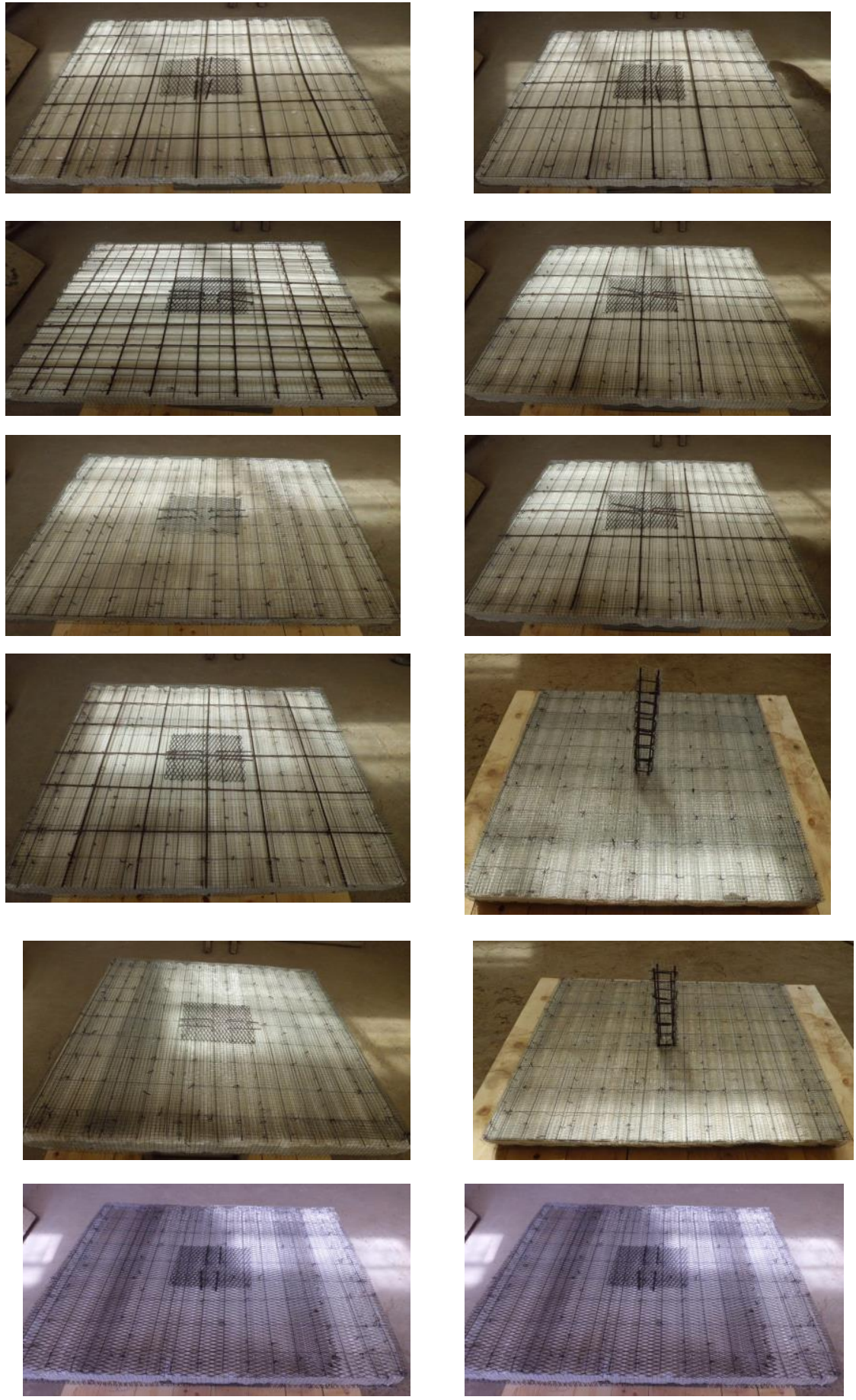

Fig.9 Reinforcement configuration of all tested light weight slabs. 

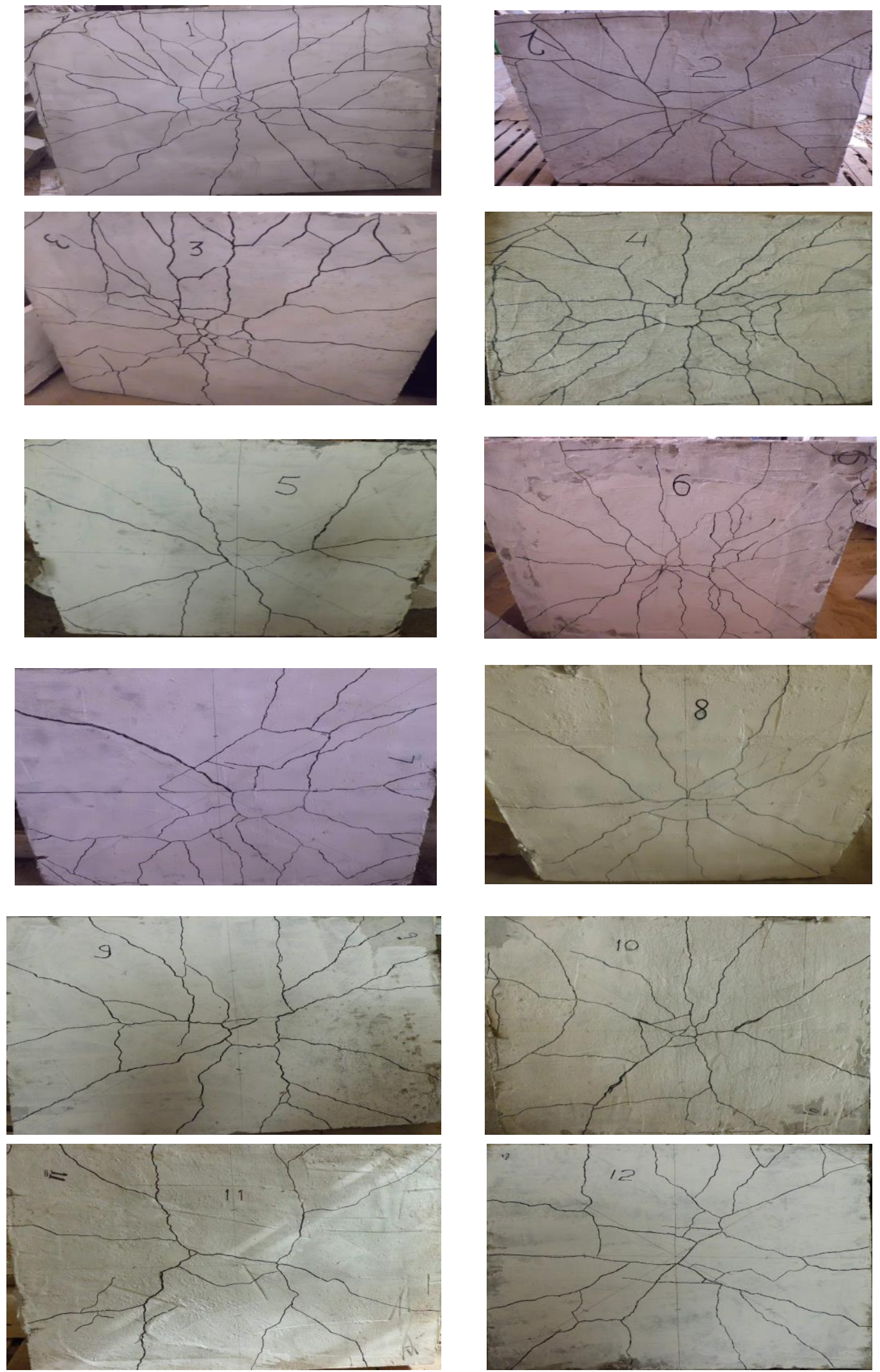

Fig.10 Cracking patterns in the tension face of all the tested slabs 